\title{
Constraining the timing of deglaciation of the High Alps and rates of subglacial erosion with cosmogenic nuclides
}

\author{
Christian Wirsig
}

\author{
E-Mail: \\ University: \\ wirsig@phys.ethz.ch \\ Supervisors: \\ Laboratory of Ion Beam Physics, ETH Zürich, Switzerland \\ Susan Ivy-Ochs, Hans-Arno Synal, Christian Schlüchter, Naki Akçar, Urs H. Fischer, Sean Willett \\ Dissertation online: http://e-collection.library.ethz.ch/view/eth:48357
}

We use in situ produced cosmogenic nuclides to study two central aspects of the impact of glaciers on the evolution of U-shaped troughs, cirques and overdeepenings in the Alps. One is the aspect of available time - how long did large glacier systems occupy the Alps in the past? The other is the pace - how fast do glaciers erode their beds?

We report chronological constraints on the onset of deglaciation in three different study areas in the High Alps; Mont Blanc in the Western Alps, Haslital in the Central Alps and Zillertal in the Eastern Alps (Wirsig et al. 2016b). In each study area we mapped glacial erosional marks (striae, crescentic gouges) and trimlines for a local reconstruction of the Last Glacial Maximum (LGM) ice surface and flow patterns. We select spots close to the trimline on exposed ridges of truncated spurs as preferred targets for dating the onset of ice surface lowering. Furthermore, we constrain the ice surface and terminal positions of local Lateglacial glacier extents by an analysis of mapping results and numerical glacier models. In the Oberhasli region (Fig. 1) we observe the first sign of ice surface lowering of the Aare Glacier at

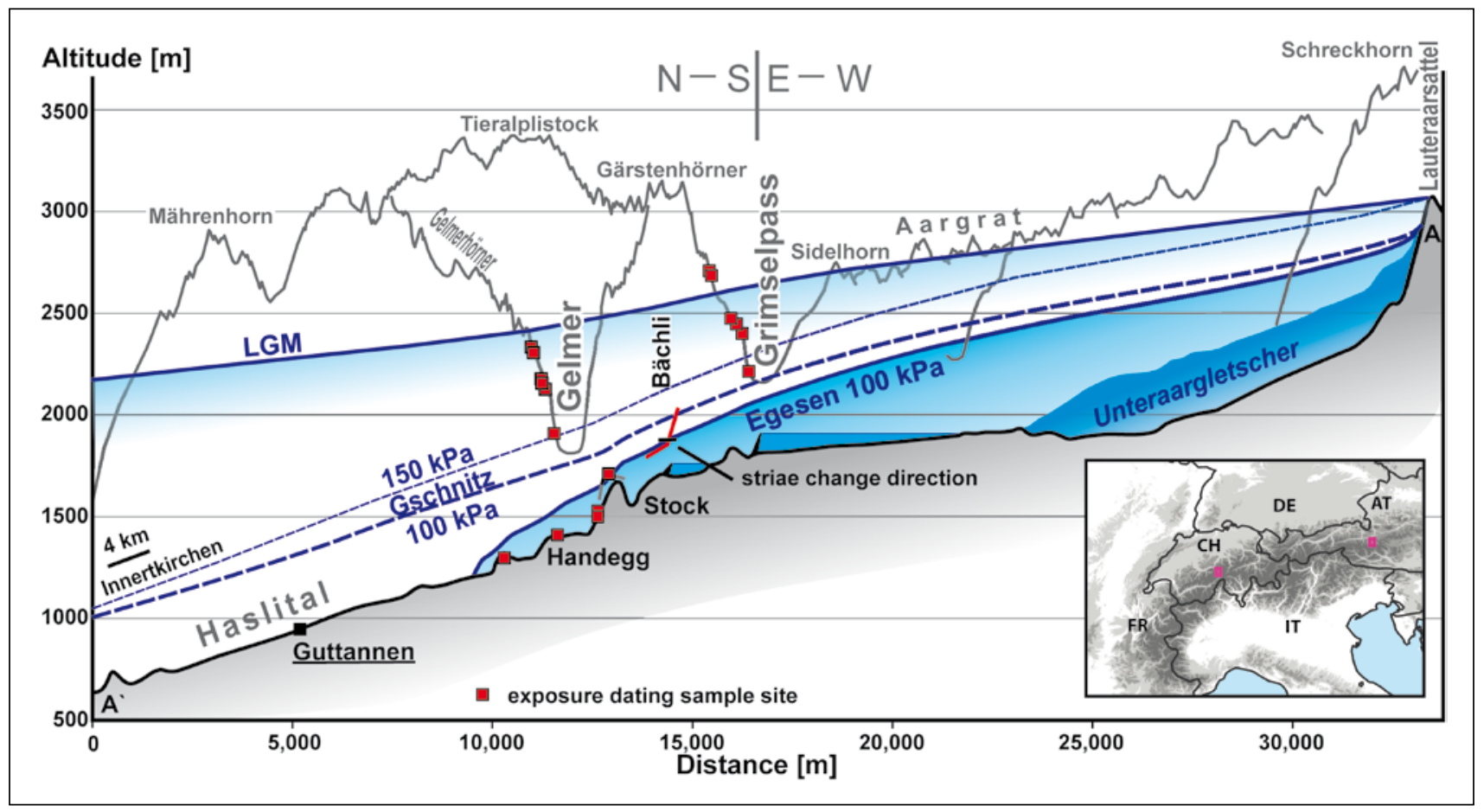

Fig. 1: Longitudinal profile from Unteraargletscher to Guttannen showing reconstructions of LGM, Gschnitz and Egesen ice surfaces (WIRSIG et al. 2016c) based on ice-flow direction indicators and surface exposure ages. Two shear stress values, $100 \mathrm{kPa}$ and $150 \mathrm{kPa}$, were used to model the Gschnitz scenarios. The Egesen ice surface (100 kPa) is constrained to be just slightly higher than Stock and lower than the directional change of striae at Bächlital (red line). Inset map shows location of Haslital (left) and Goldbergkees (right) study sites. Figure modified from WIRSIG et al. $2016 \mathrm{c}$. 

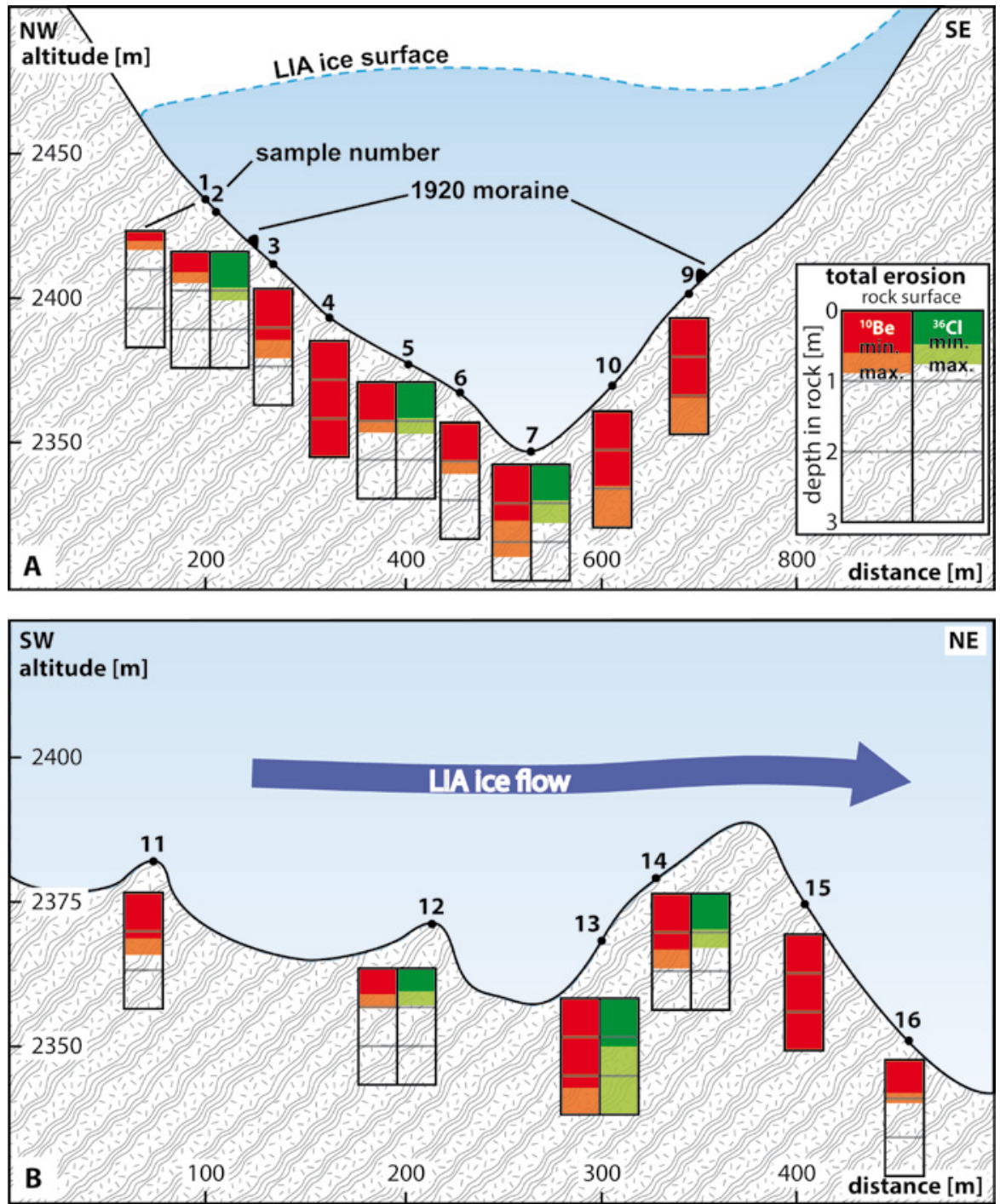

Fig. 2: Erosion depths into bedrock along A) transverse and B) longitudinal valley profiles at Goldbergkees (Austria) calculated with measured nuclide concentrations and known time of post-Little Ice Age exposure of $<100 \mathrm{yr}$ (WIRsIG et al. in press). Erosion is deepest part way up the valley sides (Gold4,9,10) and at the stoss (Gold13) and lee (Gold15) sides of the bedrock riegel. The boxes showing the erosion depths are not to scale. Note that the scale changes from A to B but vertical exaggeration $(\sim 5 x)$ stays the same. Figure modified from WIRSIG et al. in press.
$23.0 \pm 0.8 \mathrm{ka}$ (WIRSIG et al. 2016c). Published chronologies in the Alpine forelands suggest a similar date for the end of the first LGM advance phase of the piedmont lobes. An only slightly lower ice surface of the Aare Glacier was thereafter attained then abandoned at $17.7 \pm 0.8 \mathrm{ka}$. We further determine identical ages for the onset of ice surface lowering of $18.5 \pm 1.1 \mathrm{ka}$ in the Val Ferret on the southern side of the Mont Blanc massif (Western Alps) and of $18.4 \pm 1.4 \mathrm{ka}$ in Zillertal in the Eastern Alps (WIrsig et al. 2016b). The ages suggest synchronous decay of the LGM glaciers in the accumulation zones of the Western, Central and Eastern Alps.

To quantify the fundamental process of subglacial erosion we present an approach of erosion rate and burial time determination based on comparison of apparent exposure ages derived from same-sample analysis of ${ }^{10} \mathrm{Be},{ }^{14} \mathrm{C}$ and ${ }^{36} \mathrm{Cl}$ (Wirsig et al. 2016a). Due to the more complex production systematics, the production rate profile beneath the rock surface of ${ }^{36} \mathrm{Cl}$ has a different shape than the ones of ${ }^{10} \mathrm{Be}$ and ${ }^{14} \mathrm{C}$. Erosion therefore results in systematically too old apparent ${ }^{36} \mathrm{Cl}$ ages compared to ${ }^{10} \mathrm{Be}$ and ${ }^{14} \mathrm{C}$. In addition, because of the short ${ }^{14} \mathrm{C}$ half-life, decay during burial causes too young apparent ${ }^{14} \mathrm{C}$ ages compared to ${ }^{10} \mathrm{Be}$ and ${ }^{36} \mathrm{Cl}$. At Goldbergkees (Eastern Alps), we apply this approach using ${ }^{10} \mathrm{Be}$ and ${ }^{36} \mathrm{Cl}$ to quantify subglacial abrasion rates in the recently ice-free ( $<100$ years) glacier forefield. Both nuclides show that several of the analyzed surfaces were eroded by $>300 \mathrm{~cm}$ during the late Holocene (Wirsig et al. in press). Calculated subglacial abrasion rates are $>5 \mathrm{~mm} / \mathrm{a}$. The deeply eroded surfaces are from sites more than $1 \mathrm{~km}$ upvalley of the LIA glacier terminus. On the other hand, several sites were hardly erdoded at all as shown by the presence of inherited nuclides. We observe severe erosion along the lower valley flanks and both up- and downvalley of a cross-valley bedrock riegel (Fig. 2).

\section{References}

Wirsig, C., Ivy-Ochs, S., Akçar, N., Lupker, M., Hippe, K., Wacker, L., Vockenhuber, C. \& SCHLÜChter, C. (2016a): Combined cosmogenic ${ }^{10} \mathrm{Be}$, in situ ${ }^{14} \mathrm{C}$ and ${ }^{36} \mathrm{Cl}$ concentrations in proglacial bedrock constrain Holocene history and erosion depth of Grueben glacier, Switzerland. - Swiss Journal of Geosciences. DOI: 10.1007/s00015-016-0227-2

Wirsig, C., Ivy-Ochs, S., Reitner, J.M., Christr, M., Vockenhuber, C., Bichler, M. \& Reindl, M. (?): Subglacial abrasion rates at Goldbergkees, Hohe Tauern, Austria, determined from cosmogenic ${ }^{10} \mathrm{Be}$ and ${ }^{36} \mathrm{Cl}$ concentrations. - Earth Surface Processes and Landforms (in press).

Wirsig, C., Zasadni, J., Christl, M., AkçAr, N. \& Ivy-Ochs, S. (2016b): Dating the onset of LGM ice surface lowering in the High Alps. Quaternary Science Reviews 143, 37-50. http://dx.doi.org/10.1016/j. quascirev.2016.05.001

Wirsig, C., Zasadni, J., Ivy-Ochs, S., Christi, M., Kober, F. ש SchlÜCHTER, C. (2016c): A deglaciation model of the Oberhasli, Switzerland. Journal of Quaternary Science 31, 46-59. DOI: 10.1002/jqs.2831 